\title{
Vibrio azureus sp. nov., a luminous marine bacterium isolated from seawater
}

Correspondence
Susumu Yoshizawa
y_susumu@nenv.k.u-tokyo.ac.jp

\author{
Susumu Yoshizawa, ${ }^{1}$ Minoru Wada, ${ }^{1}$ Kumiko Kita-Tsukamoto, ${ }^{1}$ \\ Eiko Ikemoto, ${ }^{1}$ Akira Yokota $^{2}$ and Kazuhiro Kogure ${ }^{1}$
${ }^{1}$ Ocean Research Institute, The University of Tokyo, 1-15-1, Minamidai, Nakano-Ku, Tokyo 164-8639, Japan
${ }^{2}$ Institute of Molecular and Cellular Biosciences, The University of Tokyo, 1-1-1 Yayoi, Bunkyo-Ku, Tokyo 113-0032, Japan

Two luminous marine bacterial strains, LC2-005 ${ }^{\top}$ and LC2-102, were isolated from seawater at Kuroshio Region and Sagami Bay in Japan, respectively. These bacteria were Gram-negative, oxidase-positive, catalase-positive, motile and rod-shaped. On the basis of 16S rRNA gene sequence analysis, strains $\mathrm{LC}^{-}-005^{\top}$ and LC2-102 formed a cluster within the Vibrio harveyi species group. However, multilocus sequence analysis using five loci ( $p y r H, f t s Z, m r e B, g y r B$ and gapA) and DNA-DNA hybridization experiments indicated that these strains were distinct from the currently known Vibrio species. Additionally, these strains differ from related Vibrio species in utilization of glucose, mannitol, inositol, sorbitol, rhamnose, sucrose, melibiose and arabinose, production of lysine decarboxylase, ornithine decarboxylase, tryptophan deaminase, esterase (C4), lipase (C4), chymotrypsin, acid phosphatase, $\alpha$-glucosidase, $\beta$-glucosidase and $N$-acetyl- $\beta$ glucosaminidase and the ability to reduce nitrate to nitrite. The major fatty acids were $\mathrm{C}_{15: 0}$ iso 2$\mathrm{OH}$ and/or $\mathrm{C}_{16: 1} \omega 7 c, \mathrm{C}_{16: 0}, \mathrm{C}_{18: 1} \omega 7 c$ and $\mathrm{C}_{14: 0}$. The DNA G+C contents of strains LC2$005^{\top}$ and LC2-102 were 45.2 and $45.5 \mathrm{~mol} \%$, respectively. On the basis of the polyphasic taxonomic evidence presented in this study, it can be concluded that strains LC2-005 ${ }^{\top}$ and LC2102 belong to the same genospecies and represent a novel species of the genus Vibrio, for which the name Vibrio azureus sp. nov. is proposed. The type strain is LC2-005 ${ }^{\top}$ (=NBRC $104587^{\top}$ $=\mathrm{KCTC} 22352^{\top}$ ).
The family Vibrionaceae includes six genera: Vibrio (Baumann \& Schubert, 1984), Photobacterium (Baumann \& Baumann, 1984), Salinivibrio (Mellado et al., 1996), Grimontia (Thompson et al., 2003), Enterovibrio (Thompson et al., 2002) and Aliivibrio (Urbanczyk et al., 2007). Several species of the genus Vibrio are ubiquitous in aquatic environments, especially the ocean, and are often isolated from various organisms ranging from plankton to fish (Thompson et al., 2004). Seven species in this genus contain luminous strains: Vibrio cholerae (Palmer \& Colwell, 1991), Vibrio harveyi (Reichelt \& Baumann, 1973), Vibrio campbellii (Gomez-Gil et al., 2004), Vibrio mediterranei (Pujalte \& Garay, 1986), Vibrio orientalis

\footnotetext{
Abbreviation: MLSA, multilocus sequence analysis.

The GenBank/EMBL/DDBJ accession numbers for the 16S rRNA, gyr $B$, pyrH, fts $Z$, mreB and gapA gene sequences of strains NBRC $104587^{\top}$ and NBRC 104588 determined in this study are AB428897AB428908 (see Supplementary Table S1, available with the online version of this paper).

Two supplementary tables and eight supplementary figures are available with the online version of this paper.
}

(Yang et al., 1983), Vibrio splendidus (biotype I) (Nealson et al., 1993) and Vibrio vulnificus (Oliver et al., 1986).

Two luminescent bacterial strains, LC2- $005^{\mathrm{T}}$ and LC2-102, were isolated from seawater. To determine their taxonomic position, the 16S rRNA gene and the genes encoding urydilate kinase $(p y r H)$, a cell-division protein $(f t s Z)$, a rod-shaping protein $(m r e B)$, DNA gyrase B subunit $(g y r B)$ and glyceraldehyde-3-phosphate dehydrogenase (gapA) were analysed (Thompson et al., 2007). Based on the phylogenetic analysis, these strains formed a tight cluster in which no type strain of a known Vibrio species is grouped. This suggests that the isolates represent a novel species of the genus Vibrio. Therefore, we conducted a series of analyses to identify these isolates.

Strains LC2-005 ${ }^{\mathrm{T}}$ and LC2-102 were isolated from seawater samples obtained from Kuroshio Region $\left(32^{\circ} 30^{\prime} \mathrm{N} 138^{\circ}\right.$ $00^{\prime} \mathrm{E}$; depth, $\left.200 \mathrm{~m}\right)$ and Sagami Bay $\left(35^{\circ} 00^{\prime} \mathrm{N} 139^{\circ} 20^{\prime} \mathrm{E}\right.$; depth, $30 \mathrm{~m}$ ) during cruises KT-05-16 (13-21 July 2005) and KT-05-31 (30 November-5 December 2005) of RV 'Tansei Maru' [Ocean Research Institute, University of Tokyo, and Japan Agency for Marine-Earth Science and 
Technology (JAMSTEC)], respectively. The samples were filtered through a polycarbonate filter (pore size of $0.2 \mu \mathrm{m}$ ) (Whatman), which was then placed on half-strength marine agar 2216E (Difco) and kept at $20{ }^{\circ} \mathrm{C}$. Luminous colonies grown on the agar plate were isolated with sterile toothpicks, utilizing a CCD camera (Atto Bioscience and Technology), and transferred to new marine agar 2216E plates for reisolation. Bacterial cultures of the isolates and reference strains were stored at $-80{ }^{\circ} \mathrm{C}$ in marine broth containing $20 \%(\mathrm{v} / \mathrm{v})$ glycerol.

Cell morphology and flagella were observed by using atomic force microscopy (model SPM-9500 J2; Shimadzu) as described previously (Nishino et al., 2004). The temperature range for growth was determined by incubating the isolates on marine agar 2216E (Difco). Growth at different $\mathrm{NaCl}$ concentrations $[0.5-10.0 \%(\mathrm{w} / \mathrm{v})]$ was determined on tryptone soya agar (Difco). Catalase activity was determined by bubble formation in a $3 \% \mathrm{H}_{2} \mathrm{O}_{2}$ solution. Oxidase activity was determined by using cytochrome oxidase paper (Nissui Pharmaceutical). API 20E and API ZYM strips (bioMérieux) were used to determine physiological and biochemical characteristics, and were read after 48 and $6 \mathrm{~h}$ incubation at $20^{\circ} \mathrm{C}$, respectively. All suspension media for API test strips were supplemented with $2 \%(\mathrm{w} / \mathrm{v}) \mathrm{NaCl}$ solution. Cellular fatty acid composition (MIDI system) was determined as described previously (Xie \& Yokota, 2003). The cells were grown for $48 \mathrm{~h}$ at $20{ }^{\circ} \mathrm{C}$ on plates of marine agar $2216 \mathrm{E}$.

DNA was prepared according to the method of Marmur (1961) from cells grown on marine agar 2216E and the DNA base composition was determined by using HPLC (Mesbah et al., 1989). DNA-DNA hybridizations were carried out with photobiotin-labelled probes in microplate wells as described by Ezaki et al. (1989). Quality and quantity of DNA were determined by measuring $A_{260}$ and $A_{280}$. Only high-quality DNA with an $A_{260} / A_{280}$ ratio of $1.8-2.0$ was used. The hybridization temperature was set at $43{ }^{\circ} \mathrm{C}$. Hybridizations were performed, using five replications for each. The highest and lowest values obtained were excluded and the mean of the remaining three values was quoted as the DNA-DNA relatedness value.

A fragment (approx. $1500 \mathrm{bp}$ ) of the 16S rRNA gene was amplified from the extracted DNA by using bacterial universal primers specific to the $16 \mathrm{~S}$ rRNA gene (27F and 1492R) (Lane, 1991). The pyrH, ftsZ, mreB, gyrB and gapA genes were used for multilocus sequence analysis (MLSA) (Thompson et al., 2007). PCR primers for the five genetic loci and reaction conditions were used according to Sawabe et al. (2007). To test the evolutionary relationships of the genus Vibrio, phylogenetic analysis was performed with the program MEGA 3.1 (Kumar et al., 2004) and PHYLIP 3.67 software, developed by Dr Joe Felsenstein (http://evolution.genetics.washington.edu/phylip.html). Multiple alignments of the sequences were performed using CLUSTAL $\mathrm{W}$ (version 1.6) (Thompson et al., 1994). Distances were calculated by using the Kimura two-parameter model
(Kimura, 1980). Clustering based on the neighbour-joining (Saitou \& Nei, 1987), maximum-parsimony and maximumlikelihood methods was determined by using bootstrap values based on 1000 replications (Felsenstein, 1985). Sequence data of other Vibrio species from the online taxonomic scheme for vibrios (http://www.taxvibrio. lncc.br) and GenBank were used in this study.

$16 \mathrm{~S}$ rRNA gene sequence analysis using the neighbourjoining, maximum-parsimony and maximum-likelihood methods indicated that strains $\mathrm{LC} 2-005^{\mathrm{T}}$ and LC2-102 belong to the genus Vibrio and are included in the $V$. harveyi clade (Sawabe et al., 2007) (Fig. 1; Supplementary Fig. S1 in IJSEM Online). The closest phylogenetic neighbours were Vibrio parahaemolyticus ATCC $17802^{\mathrm{T}}$ (16S rRNA gene sequence similarity, 99.8\%), Vibrio natriegens ATCC $14048^{\mathrm{T}}$ (99.8\%) and Vibrio alginolyticus LMG $4409^{\mathrm{T}}(99.7 \%)$ and the closest neighbours belonging to luminous species were $V$. campbellii ATCC $25920^{\mathrm{T}}$ $(99.7 \%)$ and $V$. harveyi ATCC $14126^{\mathrm{T}}$ (99.6\%). DNADNA hybridization values between strain LC2 $-005^{\mathrm{T}}$ and other Vibrio species were $23.2 \%$ ( $V$. parahaemolyticus NBRC $\left.12711^{\mathrm{T}}\right), 23.0 \%\left(V\right.$. natriegens ATCC $\left.14048^{\mathrm{T}}\right)$, $24.2 \% \quad\left(V\right.$. alginolyticus ATCC $\left.17749^{\mathrm{T}}\right), 20.0 \% \quad(V$. campbellii ATCC $25920^{\mathrm{T}}$ ) and $21.4 \%$ (V. harveyi NBRC $15634^{\mathrm{T}}$ ). The DNA-DNA hybridization value between strains LC2-005 ${ }^{\mathrm{T}}$ and LC2-102 was $85.2 \%$.

The phylogenetic trees based on $p y r H, f t s Z, m r e B, g y r B$ and gapA gene sequences confirmed the clustering of strains LC2 $-005^{\mathrm{T}}$ and LC2-102, with a bootstrap value of $100 \%$, and their distinction from their closest phylogenetic neighbours $V$. parahaemolyticus, $V$. natriegens, $V$. alginolyticus, $V$. campbellii, $V$. harveyi and Vibrio rotiferianus. Similarities between pyrH gene sequences ranged between $90 \%\left(\mathrm{LC} 2-005^{\mathrm{T}}\right.$ and $V$. rotiferianus LMG $\left.21460^{\mathrm{T}}\right)$ and $85 \%\left(\mathrm{LC} 2-005^{\mathrm{T}}\right.$ and $V$. parahaemolyticus LMG $2850^{\mathrm{T}}$ ). Similarities between $\mathrm{fts} Z$ gene sequences ranged between $84 \%\left(\mathrm{LC} 2-005^{\mathrm{T}}\right.$ and $V$. parahaemolyticus LMG $2850^{\mathrm{T}}$ ) and $81 \%\left(\mathrm{LC}^{-}-005^{\mathrm{T}}\right.$ and $V$. alginolyticus LMG $\left.4409^{\mathrm{T}}\right)$. Similarities between $m r e B$ gene sequences ranged between $79 \%\left(\right.$ LC2 $^{-005^{\mathrm{T}}}$ and V. campbellii LMG $11216^{\mathrm{T}}$ ) and $77 \%$ $\left(\mathrm{LC} 2-005^{\mathrm{T}}\right.$ and $V$. alginolyticus LMG $\left.4409^{\mathrm{T}}\right)$. Similarities between gyrB gene sequences ranged between $92 \%$ (LC2$005^{\mathrm{T}}$ and $V$. rotiferianus LMG $21460^{\mathrm{T}}$ ) and $83 \%\left(\mathrm{LC} 2-005^{\mathrm{T}}\right.$ and $V$. alginolyticus LMG $4409^{\mathrm{T}}$ ). Similarities between gapA gene sequences ranged between $92 \%\left(\mathrm{LC} 2-005^{\mathrm{T}}\right.$ and $V$. parahaemolyticus LMG $2850^{\mathrm{T}}$ ) and $90 \%\left(\mathrm{LC} 2-005^{\mathrm{T}}\right.$ and $V$. alginolyticus LMG $4409^{\mathrm{T}}$ ). All phylogenetic trees are shown in Supplementary Figs S2-S6 in IJSEM Online. Phylogenetic analysis using MLSA ( $p y r H, f t s Z, m r e B$, gyrB and gapA genes) revealed that the two strains belong to a novel species in this genus (Fig. 2). A further phylogenetic tree using MLSA (16S rRNA, pyrH, ftsZ, mreB, gyrB and gapA genes) is shown in Supplementary Fig. S7 in IJSEM Online. These results demonstrate that strain LC2 $-005^{\mathrm{T}}$ is distinct from any recognized species of the genus Vibrio. The DNA G + C contents of strains LC2 $-005^{\mathrm{T}}$ and LC2-102 were 45.2 and $45.5 \mathrm{~mol} \%$, respectively. 


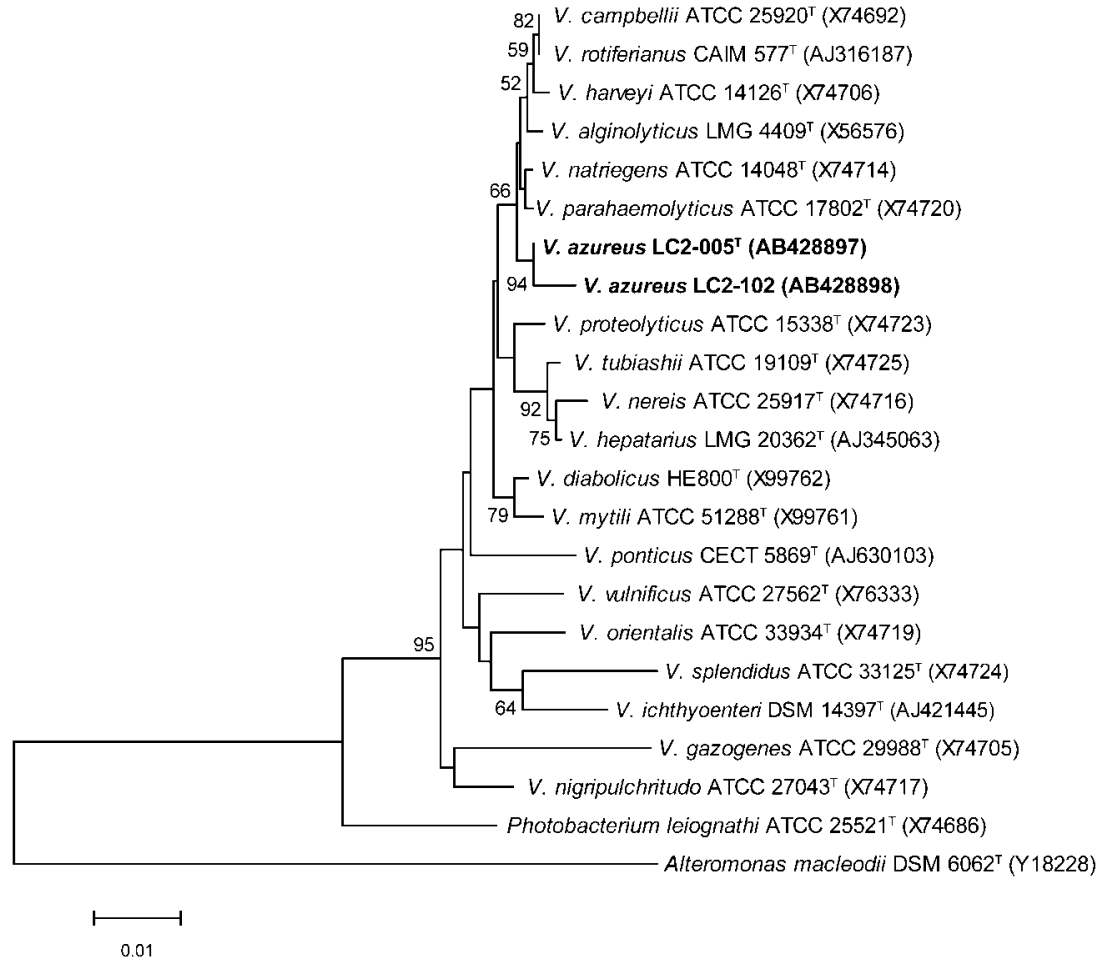

Fig. 1. Phylogenetic tree based on the neighbour-joining method, using partial 16S rRNA gene sequences. Bootstrap values are expressed as percentages of 1000 replications; only values $>50 \%$ are shown. Alteromonas macleodii was used as an outgroup. Bar, $1 \%$ estimated sequence divergence.
Both isolates are luminous, and form green colonies on thiosulfate-citrate-bile-sucrose (TCBS) agar and unpigmented, translucent colonies on marine agar. On the basis of the API 20E and API ZYM tests, the two strains can be discriminated from other Vibrio species. In contrast to most of their phylogenetic neighbours, these strains cannot reduce nitrates to nitrites, cannot produce lysine decarboxylase, ornithine decarboxylase, tryptophan deaminase, esterase (C4), lipase (C4), chymotrypsin, acid phosphatase, $\alpha$-glucosidase, $\beta$-glucosidase or $N$-acetyl- $\beta$ glucosaminidase and cannot utilize mannitol, inositol, sorbitol or sucrose (Table 1).

The predominant cellular fatty acids of strains LC2- $005^{\mathrm{T}}$ and $\mathrm{LC} 2-102$ are $\mathrm{C}_{15: 0}$ iso 2-OH and/or $\mathrm{C}_{16: 1} \omega 7 c(37.7$ and $41.3 \%$, respectively), $\mathrm{C}_{18: 1} \omega 7 c$ (18.5 and $\left.8.4 \%\right), \mathrm{C}_{16: 0}$ (15.8 and $16.8 \%$ ) and $\mathrm{C}_{14: 0}(6.1$ and $9.3 \%)$. For other fatty acids, see Supplementary Table S2 in IJSEM Online and the species description, but no clear differences from type strains of related species in the genus Vibrio were observed.

Morphological, cultural, physiological and biochemical characteristics of strain LC2- $005^{\mathrm{T}}$ are given in the species description or are shown in Table 1 and Supplementary Fig. S8 (available in IJSEM Online). These results show that strain $\mathrm{LC} 2-005^{\mathrm{T}}$ is related closely to the $V$. harveyi clade, but can be differentiated from closely related species based on phylogenetic analysis, DNA-DNA similarity and several phenotypic traits. The new strains can also be differentiated from all known Vibrio species based on a combination of physiological characteristics: luminescence, production of protease and decarboxylase, and nitrate reduction. Therefore, strains $\mathrm{LC} 2-005^{\mathrm{T}}$ and LC2-102 should be identified as members of a novel species in the genus Vibrio, for which the name Vibrio azureus sp. nov. is proposed.

\section{Description of Vibrio azureus sp. nov.}

Vibrio azureus (a.zur'e.us. N.L. masc. adj. azureus azure blue, referring to the colour of emitted light).

Gram-negative, oxidase-positive, catalase-positive and motile by means of more than one polar flagellum. Nonpigmented, translucent, luminescent colonies with weak swarming are formed on marine agar. Round, 5-7 mm green colonies are formed on TCBS agar. Growth occurs in the presence of $0.5,2.0,3.5$ and $6.0 \% \mathrm{NaCl}(\mathrm{w} / \mathrm{v})$, but not at 8.0 or $10.0 \% \mathrm{NaCl}$; growth occurs at $10-37{ }^{\circ} \mathrm{C}$, but not at $4{ }^{\circ} \mathrm{C}$. Positive for indole production and fermentation of glucose and amygdalin. Positive enzyme activities are seen for protease, alkaline phosphatase, esterase lipase (C8), leucine arylamidase, naphthol-AS-BI-phosphohydrolase and $N$-acetyl- $\beta$-glucosaminidase. Major fatty acids are $\mathrm{C}_{15: 0}$ iso $2-\mathrm{OH}$ and/or $\mathrm{C}_{16: 1} \omega 7 c, \mathrm{C}_{18: 1} \omega 7 c, \mathrm{C}_{16: 0}, \mathrm{C}_{14: 0}$, $\mathrm{C}_{12: 0}, \mathrm{C}_{17: 1} \omega 8 c, \mathrm{C}_{16: 1}$ iso $\mathrm{I}$ and/or $\mathrm{C}_{14: 0} 3-\mathrm{OH}, \mathrm{C}_{15: 0}$, $\mathrm{C}_{18: 0}, \mathrm{C}_{17: 0}, \mathrm{C}_{16: 0} \omega 7 c$ alcohol and $\mathrm{C}_{12: 0} 3-\mathrm{OH}$. The DNA $\mathrm{G}+\mathrm{C}$ content of the type strain is $45.2 \mathrm{~mol} \%$.

The type strain is $\mathrm{LC} 2-005^{\mathrm{T}}$ (=NBRC $104587^{\mathrm{T}}=\mathrm{KCTC}$ $22352^{\mathrm{T}}$ ), isolated from seawater of Kuroshio Region, Japan. Reference strain is LC2-102 (=NBRC 104588 $=$ KCTC 22353). 


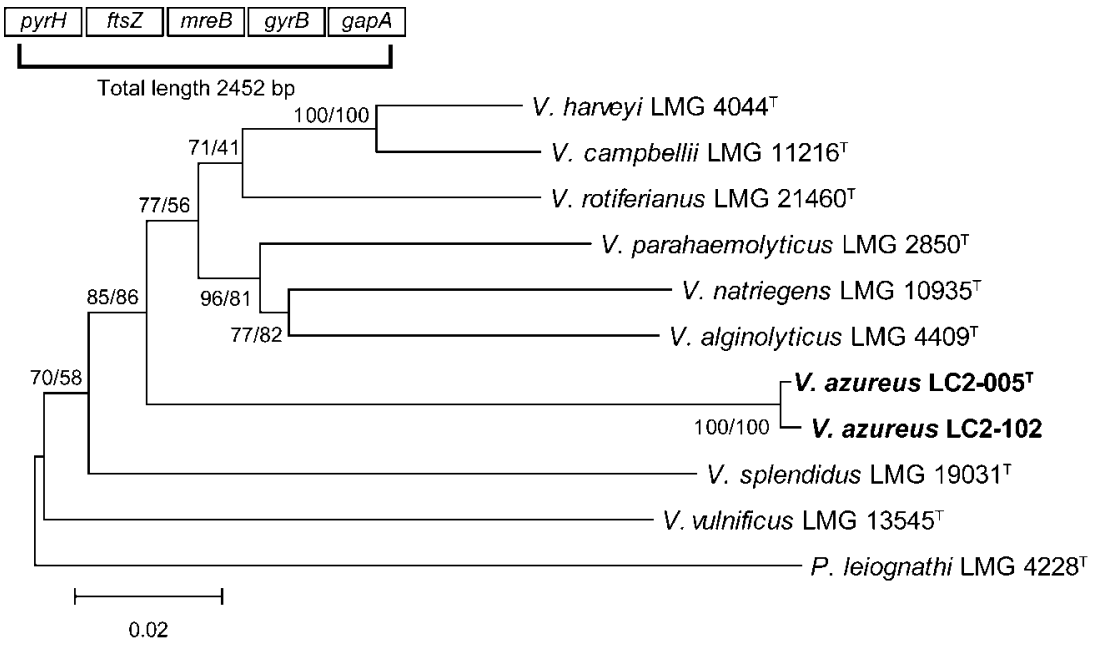

Fig. 2. Phylogenetic tree based on the concatenated gene sequences of the five loci (2452 bp). This tree combines the results of both the neighbour-joining ( $\mathrm{NJ}$ ) and maximumparsimony (MP) methods. The topology shown was obtained by using the NJ method. Numbers at nodes denote the level of bootstrap support (\%) based on 1000 replicates (NJ/MP). Photobacterium leiognathi was used as an outgroup. Bar, $2 \%$ sequence divergence.

Table 1. Differential phenotypic characteristics of Vibrio azureus sp. nov. and related species of the genus Vibrio

Taxa: 1, strain LC2-005 ${ }^{\mathrm{T}}$; 2, strain LC2-102; 3, V. parahaemolyticus NBRC $12711^{\mathrm{T}}$; 4, V. alginolyticus ATCC $17749^{\mathrm{T}}$; 5, V. harveyi NBRC $15634^{\mathrm{T}}$; 6, V. campbellii ATCC $25920^{\mathrm{T}}$; 7, V. natriegens ATCC $14048^{\mathrm{T}}$. +, Positive; w, weakly positive; -, negative; G, green; Y, yellow.

\begin{tabular}{|c|c|c|c|c|c|c|c|}
\hline Characteristic & 1 & 2 & 3 & 4 & 5 & 6 & 7 \\
\hline Luminescence & + & + & - & - & + & - & - \\
\hline \multicolumn{8}{|l|}{ Production of: } \\
\hline Lysine decarboxylase & - & - & - & + & + & - & - \\
\hline Ornithine decarboxylase & - & - & + & - & - & - & - \\
\hline Tryptophan deaminase & - & - & - & + & $\mathrm{w}$ & $\mathrm{w}$ & + \\
\hline Esterase (C4) & - & - & $\mathrm{w}$ & - & - & $\mathrm{w}$ & - \\
\hline Lipase (C4) & - & - & - & $\mathrm{w}$ & - & $\mathrm{w}$ & - \\
\hline Chymotrypsin & - & - & - & - & - & + & - \\
\hline Acid phosphatase & - & - & + & + & + & - & + \\
\hline$\alpha$-Glucosidase & - & - & $\mathrm{w}$ & $\mathrm{w}$ & $\mathrm{w}$ & - & + \\
\hline$N$-Acetyl- $\beta$-glucosaminidase & + & w & - & w & - & - & - \\
\hline Citrate utilization & - & - & - & + & - & - & - \\
\hline Indole production & $\mathrm{w}$ & + & + & + & + & + & - \\
\hline Reduction of nitrate to nitrite & - & - & + & + & + & - & + \\
\hline \multicolumn{8}{|l|}{ Fermentation of: } \\
\hline Glucose & $\mathrm{w}$ & w & + & + & $\mathrm{w}$ & - & w \\
\hline Mannitol & - & - & + & + & + & + & + \\
\hline Inositol & - & - & $\mathrm{w}$ & $\mathrm{w}$ & $\mathrm{w}$ & $\mathrm{w}$ & $\mathrm{w}$ \\
\hline Sorbitol & - & - & $\mathrm{w}$ & $\mathrm{w}$ & - & w & $\mathrm{w}$ \\
\hline Rhamnose & - & - & - & - & - & - & + \\
\hline Sucrose & - & - & w & + & + & + & + \\
\hline Melibiose & - & - & - & - & $\mathrm{w}$ & w & w \\
\hline Arabinose & - & - & - & w & - & - & + \\
\hline \multicolumn{8}{|l|}{ Growth in $\mathrm{NaCl}(\%, \mathrm{w} / \mathrm{v})$ : } \\
\hline 8 & - & - & $\mathrm{w}$ & + & - & - & + \\
\hline 10 & - & - & - & $\mathrm{w}$ & - & - & - \\
\hline Colony colour on TCBS agar & G & G & G & $\mathrm{Y}$ & $\mathrm{Y}$ & $-*$ & $\mathrm{Y}$ \\
\hline DNA G $+\mathrm{C}$ content $(\mathrm{mol} \%)$ & 45.2 & 45.5 & $46-47 \dagger$ & $45-47 \dagger$ & $46-48 \dagger$ & $46-48 \dagger$ & $45.1-47.0 \dagger$ \\
\hline
\end{tabular}

${ }^{\star} V$. campbellii could not grow on TCBS agar.

$\dagger$ Data were described by Farmer et al. (2005). 


\section{Acknowledgements}

We are grateful to Dr Jaewoo Yoon (Department of Biotechnology, The University of Tokyo, Japan) for technical support. This work was supported by the Sasakawa Scientific Research Grant from the Japan Science Society and a research grant from the Institute for Fermentation, Osaka, Japan.

\section{References}

Baumann, P. \& Baumann, L. (1984). Genus II. Photobacterium Beijerinck 1889, $401^{\mathrm{AL}}$. In Bergey's Manual of Systematic Bacteriology, vol. 1, pp. 539-545. Edited by N. R. Krieg \& J. G. Holt. Baltimore, MD: Williams \& Wilkins.

Baumann, P. \& Schubert, R. H. W. (1984). Family II. Vibrionaceae Veron 1965, 5245 ${ }^{\mathrm{AL}}$. In Bergey's Manual of Systematic Bacteriology, vol. 1, pp. 516-517. Edited by N. R. Krieg \& J. G. Holt. Baltimore, MD: Williams \& Wilkins.

Ezaki, T., Hashimoto, Y. \& Yabuuchi, E. (1989). Fluorometric deoxyribonucleic acid-deoxyribonucleic acid hybridization in microdilution wells as an alternative to membrane filter hybridization in which radioisotopes are used to determine genetic relatedness among bacterial strains. Int J Syst Bacteriol 39, 224-229.

Farmer, J. J., III, Janda, J. M., Brenner, F. W., Cameron, D. N. \& Birkhead, K. M. (2005). Genus I. Vibrio Pacini $1854,411^{\mathrm{AL}}$. In Bergey's Manual of Systematic Bacteriology, 2nd edn, vol. 2 part B, pp. 494-546. Edited by D. J. Brenner, N. R. Krieg \& J. T. Staley. New York: Springer.

Felsenstein, J. (1985). Confidence limits on phylogenies: an approach using the bootstrap. Evolution 39, 783-791.

Gomez-Gil, B., Soto-Rodriguez, S., Garcia-Gasca, A., Roque, A., Vazquez-Juarez, R., Thompson, F. L. \& Swings, J. (2004). Molecular identification of Vibrio harveyi-related isolates associated with diseased aquatic organisms. Microbiology 150, 1769-1777.

Kimura, M. (1980). A simple method for estimating evolutionary rates of base substitutions through comparative studies of nucleotidesequences. J Mol Evol 16, 111-120.

Kumar, S., Tamura, K. \& Nei, M. (2004). MEGA3: integrated software for molecular evolutionary genetics analysis and sequence alignment. Brief Bioinform 5, 150-163.

Lane, D. J. (1991). 16S/23S rRNA sequencing. In Nucleic Acid Techniques in Bacterial Systematics, pp. 115-175. Edited by E. Stackebrandt \& M. Goodfellow. Chichester, UK: Wiley.

Marmur, J. (1961). A procedure for the isolation of deoxyribonucleic acid from microorganisms. J Mol Biol 3, 208-218.

Mellado, E., Moore, E. R. B., Nieto, J. J. \& Ventosa, A. (1996). Analysis of 16S rRNA gene sequences of Vibrio costicola strains: description of Salinivibrio costicola gen. nov., comb. nov. Int J Syst Bacteriol 46, 817821.

Mesbah, M., Premachandran, U. \& Whitman, W. B. (1989). Precise measurement of the $\mathrm{G}+\mathrm{C}$ content of deoxyribonucleic acid by highperformance liquid chromatography. Int J Syst Bacteriol 39, 159-167.

Nealson, K. H., Wimpee, B. \& Wimpee, C. (1993). Identification of Vibrio splendidus as a member of the planktonic luminous bacteria from the persian gulf and Kuwait region with luxa probes. Appl Environ Microbiol 59, 2684-2689.

Nishino, T., Ikemoto, E. \& Kogure, K. (2004). Application of atomic force microscopy to observation of marine bacteria. J Oceanogr $\mathbf{6 0}$, 219-225.

Oliver, J. D., Roberts, D. M., White, V. K., Dry, M. A. \& Simpson, L. M. (1986). Bioluminescence in a strain of the human pathogenic bacterium Vibrio vulnificus. Appl Environ Microbiol 52, 1209-1211.

Palmer, L. M. \& Colwell, R. R. (1991). Detection of luciferase gene sequence in nonluminescent Vibrio cholerae by colony hybridization and polymerase chain reaction. Appl Environ Microbiol 57, 12861293.

Pujalte, M.-J. \& Garay, E. (1986). Proposal of Vibrio mediterranei sp. nov.: a new marine member of the genus Vibrio. Int J Syst Bacteriol 36, 278-281.

Reichelt, J. L. \& Baumann, P. (1973). Taxonomy of the marine, luminous bacteria. Arch Mikrobiol 94, 283-330.

Saitou, N. \& Nei, M. (1987). The neighbor-joining method: a new method for reconstructing phylogenetic trees. Mol Biol Evol 4, 406425.

Sawabe, T., Kita-Tsukamoto, K. \& Thompson, F. L. (2007). Inferring the evolutionary history of vibrios by means of multilocus sequence analysis. J Bacteriol 189, 7932-7936.

Thompson, J. D., Higgins, D. G. \& Gibson, T. J. (1994). CLUSTAL W: improving the sensitivity of progressive multiple sequence alignment through sequence weighting, position-specific gap penalties and weight matrix choice. Nucleic Acids Res 22, 4673-4680.

Thompson, F. L., Hoste, B., Thompson, C. C., Goris, J., Gomez-Gil, B., Huys, L., De Vos, P. \& Swings, J. (2002). Enterovibrio norvegicus gen. nov., sp nov., isolated from the gut of turbot (Scophthalmus maximus) larvae: a new member of the family Vibrionaceae. Int J Syst Evol Microbiol 52, 2015-2022.

Thompson, F. L., Hoste, B., Vandemeulebroecke, K. \& Swings, J. (2003). Reclassification of Vibrio hollisae as Grimontia hollisae gen. nov., comb. nov. Int J Syst Evol Microbiol 53, 1615-1617.

Thompson, F. L., lida, T. \& Swings, J. (2004). Biodiversity of vibrios. Microbiol Mol Biol Rev 68, 403-431.

Thompson, F. L., Gomez-Gil, B., Vasconcelos, A. T. R. \& Sawabe, T. (2007). Multilocus sequence analysis reveals that Vibrio harveyi and $V$. campbellii are distinct species. Appl Environ Microbiol 73, 4279-4285.

Urbanczyk, H., Ast, J. C., Higgins, M. J., Carson, J. \& Dunlap, P. V. (2007). Reclassification of Vibrio fischeri, Vibrio logei, Vibrio salmonicida and Vibrio wodanis as Alivibrio fischeri gen. nov., comb. nov., Aliivibrio logei comb. nov., Aliivibrio salmonicida comb. nov. and Aliivibrio wodanis comb. nov. Int J Syst Evol Microbiol 57, 28232829.

Xie, C. H. \& Yokota, A. (2003). Phylogenetic analyses of Lampropedia hyalina based on the 16S rRNA gene sequence. J Gen Appl Microbiol 49, 345-349.

Yang, Y., Yeh, L., Cao, Y., Baumann, L., Baumann, P., Tang, J. S. \& Beaman, B. (1983). Characterization of marine luminous bacteria isolated off the coast of China and description of Vibrio orientalis sp. nov. Curr Microbiol 8, 95-100. 